\title{
Penerapan Water Safety Plans (WSP)-Komunitas dalam Penyediaan Air Minum Berbasis Masyarakat di Kelurahan Bangetayu Kulon Kecamatan Genuk Kota Semarang
}

\author{
Saura Olivia Effendi 1 \\ PT Angkasa Pura II (Persero) \\ Tangerang, Banten, Indonesia
}

\begin{abstract}
Abstrak: Water safety plan (WSP) didefinisikan sebagai pendekatan penilaian risiko yang komprehensif dan pendekatan manajemen risiko untuk memastikan keamanan pasokan air minum yang mencakup semua tahapan dalam pasokan air, dari sumber hingga pelanggan dengan target berbasis kesehatan (Sam Godfrey and Guy Howard, 2004 dan WHO, 2009). Konsep WSP yang dikembangkan mencakup empat elemen dasar yaitu: WSP-Sumber, WSP-Operator, WSP- Komunitas, dan WSP-Konsumen. Penerapan WSP di Indonesia akan ditekankan pada konsep WSP-Komunitas. Pamsimas merupakan program pemerintah berbasis komunitas dalam pemenuhan dan pengamanan air yang bertujuan meningkatkan akses pelayanan air minum dan sanitasi bagi masyarakat miskin perdesaan dan daerah pinggiran kota. Bulan Februari 2012, BPSPAMS Tirto Makmur Abadi Kelurahan Bangetayu Kulon Kota Semarang menempati ranking pertama di Kota Semarang Tahun 2012. Berdasarkan uraian di atas, peneliti ingin mengkaji apakah konsep WSP-komunitas telah diterapkan dalam penyediaan air minum berbasis masyarakat oleh Pamsimas di Kelurahan Bangetayu Kulon Kecamatan Genuk Kota Semarang. Pendekata $n$ penelitian yang digunakan adalah pendekatan penelitian campuran (gabungan kualitatif dan kuantitatif). Berdasarkan hasil identifikasi dan analisis, pelaksanaan penyediaan air minum oleh Pamsimas di Kelurahan Bangetayu Kulon masih belum sesuai dengan penerapan konsep WSP- Komunitas. Dari 5 komponen penerapan WSP, belum ada kriteria yang telah dilaksanakan oleh Pamsimas terkait sistem pengamanan air minum. Pamsimas belum menerapkan sistem pengamanan seperti konsep WSP, dimana langkah pengamanan baru ditentukan saat program selesai dilaksanakan dan dampak telah dirasakan.
\end{abstract}

Kata Kunci: Penyediaan air minum, Pamsimas, Water Safety Plan (WSP)

\begin{abstract}
Water safety plan (WSP) is defined as a comprehensive approach to risk assessment and risk management approach to ensure the safety of drinking water supplies covers all stages in the supply of water, from the source to the customer with the healthbased targets (Sam Godfrey and Guy Howard, 2004 and WHO, 2009). The concept developed by WSP includes four basi c elements, namely: WSP-Sources, WSP-Operator, WSP-Community, and WSP-Consumer. Implementation of WSP in Indonesia will focus on community WSP concept. The research approach used is a mixture of research approach (a combi nation of qualitative and quantitative). Pamsimas is a government
\end{abstract}

\footnotetext{
${ }^{1}$ Korenspondensi Penulis: PT Angkasa Pura II (Persero), Tangerang, Banten

Email: sauraolivia@yahoo.com
} 


\section{Penerapan Water Safety Plans (WSP)-Komunitas dalam Penyediaan Air Minum Berbasis Masyarakat}

program in a community-based compliance and water safety aimed at improving access to drinking water and sanitation for the poor rural and suburban areas. In February 2012, BPSPAMS Tirto Makmur Abadi Bangetayu Kulon Semarang City ranked first in the city of Semarang in 2012. Based on the above, the researchers wanted to examine whether the WSP-community concept has been applied in community-based drinking water supply by Pamsimas in Bangetayu Kulon village Genuk Subdistrict of Semarang. According to identification and analysis results, implementation of water supply by Pamsimas in Bangetayu Kulon village still not in accordance with the application of the community WSP concept. Pamsimas have not implemented security systems such as WSP concept, where new security measures are determined when the program is completed and the impact has been felt.

Keywords: drinking water supply, Pamsimas, Water Safety Plan (WSP)

\section{Pendahuluan}

Water safety plan didefinisikan sebagai pendekatan penilaian risiko yang komprehensif dan pendekatan manajemen risiko untuk memastikan keamanan pasokan air minum yang mencakup semua tahapan dalam pasokan air, dari sumber hingga pelanggan (Sam Godfrey and Guy Howard, 2004 dan WHO, 2009). Poin utamanya adalah mencakup semua tahapan merupakan dasar prinsip WSP, karena kontaminasi dapat terjadi pada setiap titik. Komponen WSP terdiri dari pengamanan sistem penyediaan air minum mulai dari sasaran atau target berbasis kesehatan untuk kualitas air, melakukan pendekatan penilaian sistem, melakukan pemantauan operasional tindakan pengendalian, mengembangkan pendokumentasian rencana manajemen dan memberikan pengawasan kesehatan publik dan sistem verifikasi kualitas air. Konsep WSP yang dikembangkan mencakup empat elemen dasar yaitu: WSP-Sumber, WSP-Operator, WSP-Komunitas, dan WSP-Konsumen. Penerapan WSP di Indonesia akan ditekankan pada konsep WSP-Komunitas.

Berdasarkan data Riskesdas 2010 sedikitnya 52\% penduduk masih mengkonsumsi air yang tidak sehat dari sumber yang tidak aman. Masalah intrusi air laut di Kota Semarang telah masuk kedaratan menjorok sampai wilayah, Tugu, Jalan Sudirman, Jalan Pandanaran, kawasan Simpang Lima, Jalan Majapahit, Pedurungan dan Kawasan Genuk, kurang lebih sejauh $6 \mathrm{~km}$ dari garis pantai. Pada daerah-daerah tersebut, sampai kedalaman 40 meter air tanah sudah payau.

Pamsimas atau penyediaan air minum dan sanitasi berbasis masyarakat merupakan salah satu program pemerintah berbasis komunitas dalam pemenuhan dan pengamanan air minum. Pamsimas secara umum bertujuan untuk meningkatkan akses pelayanan air minum dan sanitasi bagi masyarakat miskin perdesaan dan daerah pinggiran kota (periurban) serta menerapkan praktik hidup bersih dan sehat dengan membangun model penyediaan prasarana dan sarana air minum dan sanitasi berbasis masyarakat yang berkelanjutan dan mampu diadaptasi oleh masyarakat dalam upaya mencapai target MDGs.

Badan Pengelola Sarana Penyedia Air Minum dan Sanitasi Tirto Makmur Abadi Kelurahan Bangetayu Kulon Kecamatan Genuk Kota Semarang menempati ranking pertama di Kota Semarang sebagai calon penerima HID (Hibah Insentif Desa) Tahun 2012. Dalam artian, BPSPAMS Tirto Makmur Abadi mempunyai kinerja baik, dengan capaian hasil yang baik pula. Berdasarkan uraian di atas, perlu dikaji lebih lanjut apakah konsep Water Safety Plans (WSP)-komunitas telah diterapkan dalam penyediaan air minum berbasis masyarakat oleh Pamsimas di Kelurahan Bangetayu Kulon Kecamatan Genuk Kota Semarang. 
Tujuan penelitian ini adalah untuk mengkaji perbandingan antara penerapan Water Safety Plans (WSP)- komunitas dan penyediaan air minum berbasis masyarakat oleh Pamsimas di Kelurahan Bangetayu Kulon Kecamatan Genuk Kota Semarang. Sasaran yang ingin diperoleh dari penelitian ini adalah mengidentifikasi sistem penyediaan air minum berbasis masyarakat oleh Pamsimas di Kelurahan Bangetayu Kulon, menganalisis dan menghitung efektivitas sistem penyediaan air minum oleh Pamsimas di Kelurahan Bangetayu Kulon, menganalisis perbandingan antara penerapan konsep WSP-Komunitas dan penyediaan air minum oleh Pamsimas di Kelurahan Bangetayu Kulon serta merumuskan sintesis teori penyediaan dan pengamanan air minum berbasis komunitas berdasarkan temuan studi dan memberikan rekomendasi.

\section{Metode Penelitian}

Pendekatan penelitian yang digunakan adalah pendekatan penelitian campuran (gabungan kualitatif dan kuantitatif) dengan metode analisis statistik deskriptif. Analisis yang dilakukan adalah analisis deskriptif identifikasi penyediaan air minum berbasis masyarakat oleh Pamsimas, analisis efektivitas sistem penyediaan air minum oleh Pamsimas dan perbandingan antara penerapan konsep WSP-Komunitas dan penyediaan air minum oleh Pamsimas di Kelurahan Bangetayu Kulon secara kualitatif dan kuantitatif. Sumber data diperoleh dari data primer melalui observasi lapangan, wawancara dan kuesioner. Dimana sampel penelitian yang digunakan adalah 74 responden masyarakat pengguna air Pamsimas. Data sekunder diperoleh dari badan pengelola dan instansi terkait.

\section{Gambaran Umum Sistem Penyediaan Air Minum di Kelurahan Bangetayu Kulon}

Objek dalam penelitian ini adalah program Pamsimas (Penyediaan Air Minum dan Sanitas Berbasis Masyarakat) di Kelurahan Bangetayu Kulon, Kecamatan Genuk Kota Semarang. Kelurahan Bangetayu Kulon dipilih karena BPSPAMS (Badan Pengelola Sarana Penyedia Air Minum dan Sanitasi Berbasis Masyarakat) Tirto Makmur Abadi di Kelurahan Bangetayu Kulon memiliki kinerja terbaik dan memperoleh Hibah Insentif Desa (HID) di Kota Semarang Tahun 2012. Luas Kelurahan ini adalah 172,18 Ha dan jumlah penduduk Tahun 2010 adalah 11270 jiwa. Pamsimas di kelurahan ini terdapat di RW V dengan cakupan pelayanan $286 \mathrm{KK}$. Penggunaan lahan di Kelurahan Bangetayu Kulon terdiri dari permukiman, fasilitas umum, kebun dan sawah. Penggunaan lahan didominasi oleh penggunaan lahan permukiman, yaitu 69,01\%.

Kondisi awal penyediaan air minum di Kelurahan Bangetayu Kulon, berdasarkan pemetaan sosial terdiri dari kelompok kurang mampu (miskin) 40,9\%, kelompok menengah (cukup) 35,4\% dan kelompok kaya (mampu) 23,7\%. Masyarakat sebagian memenuhi kebutuhan air minum dengan sumur gali dengan kualitas air yang payau, berbau dan berwarna keruh. Sanitasi belum memadai/belum sanitair. Sebagian masih ada yang buang air besar sembarangan (BABS + 30\%). Mereka buang air besar di sungai, di kebun atau di sawah. Sarana air minum yang ada di Kelurahan Bangetayu Kulon antara lain berupa perpipaan, sumur dangkal atau sumur gali dan sumur artetis.

Jumlah kepala keluarga (KK) pengguna PDAM di Kelurahan Bangetayu Kulon sebanyak $40 \mathrm{KK}$ (1,3\%), sedangkan pelanggan non PDAM adalah $2938 \mathrm{KK}(98,7 \%)$. Rumah tangga miskin merupakan kelompok masyarakat yang memiliki akses rendah terhadap air minum (Buku Laporan Hasil Identifikasi Masalah dan Analisis Situasi dan Penyusunan PJM Proaksi Pamsimas, 2009). Profil BPSPAMS Kelurahan Bangetayu Kulon dapat dilihat pada gambar berikut. 


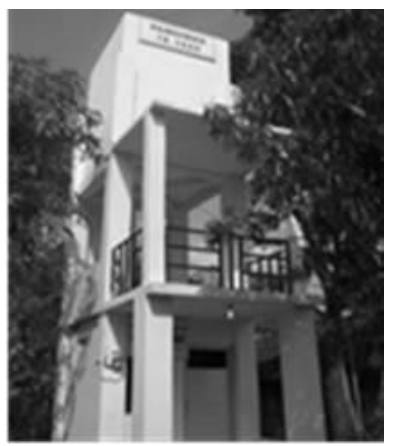

Nama BPSPAMS

Ketua

Alamat

Capaian

Biaya Pemasangan I

Abonemen

pemakaian $/ \mathrm{m}^{3}$
: Tirto Makmur Abadi

: Kurniawan

: Jl Widuri II/17 RT 03 RW 05 Bangetayu Kulon

: $286 \mathrm{SR}$

: Rp. 500.000

:Rp. 2000,- Biaya

:Rp. 1.500,-

Sumber: BPSPAMS, 2011

\section{Gambar 1. Profil BPSPAMS Kelurahan Bangetayu Kulon 2009}

\section{Kajian Teori}

\section{Sistem Penyediaan Air Minum}

Untuk meneliti sistem penyediaan air minum, ditinjau dari 4 aspek, yaitu aspek teknik, aspek finansial, aspek kelembagaan dan aspek peran serta masyarakat (Brikké, 2003 dalam Masduqi, 2009).

\section{Efektivitas sistem penyediaan air minum oleh Pamsimas}

Efektivitas penyediaan air minum oleh Pamsimas, dilihat dari 3 hal berdasarkan komponen Pamsimas, yaitu: pemberdayaan masyarakat dan pengembangan kelembagaan lokal, peningkatan perilaku hidup bersih dan sehat, layanan higienis dan sanitasi, serta penyediaan sarana air minum dan sanitasi umum. Di dalam ketiga aspek tersebut sudah mencakup akses masyarakat (terutama miskin) terhadap air minum dan sanitasi yang layak, tingkat kepuasan masyarakat terhadap kualitas, kuantitas dan kontinuitas aliran air, serta keterjangkauan biaya/tarif dan keterlibatan stakeholder (Rajabi 1999 dan Masduqi, 2009).

\section{Perbandingan antara Penerapan Konsep WSP-Komunitas dan Penyediaan Air Minum Berbasis Masyarakat oleh Pamsimas}

Komponen yang akan dibandingkan dalam penelitian ini adalah manajemen pengamanan air minum mulai, dilihat dari segi kinerja dan output dari manajemen tersebut. Penerapan konsep WSP-Komunitas dalam penyediaan air minum berbasis masyarakat yang telah diterapkan sebelumnya dapat diteliti melalui komponennya, yang terdiri dari: pendekatan pengamanan sistem penyediaan air minum mulai dari sasaran atau target berbasis kesehatan untuk kualitas air, melakukan pendekatan penilaian sistem, melakukan pemantauan operasional tindakan pengendalian, mengembangkan pendokumentasian rencana manajemen dan memberikan pengawasan kesehatan publik dan sistem verifikasi kualitas air (Sam Godfrey and Guy Howard, 2004 dan WHO, 2009) yang telah dilakukan oleh Pamsimas untuk menjamin keamanan air dilihat dari 4 aspek, kuantitas, kualitas, kontinuitas dan keterjangkauan air bagi masyarakat. 


\section{Sistem Penyediaan Air Minum Berbasis Masyarakat oleh Pamsimas}

Sistem penyediaan air minum oleh Pamsimas di Kelurahan Bangetayu Kulon menggunakan sumber air tanah dalam yang diperoleh dengan pengeboran sedalam $120 \mathrm{~m}$, kemudian ditampung dalam menara air dengan kapasitas $8 \mathrm{~m} 3$ untuk didistribusikan ke 286 sambungan rumah di RW V. Secara finansial, didanai oleh pemerintah dan masyarakat, kemudian dikelola oleh BPSPAMS Tirto Makmur Abadi. Disetiap tahapan program Pamsimas telah melibatkan semua golongan masyarakat, namun masih dalam jumlah yang kecil. Berikut adalah bagan sistem penyediaan air minum oleh Pamsimas di RW V Kelurahan Bangetayu Kulon mulai dari sumber hingga pelayanan konsumen.

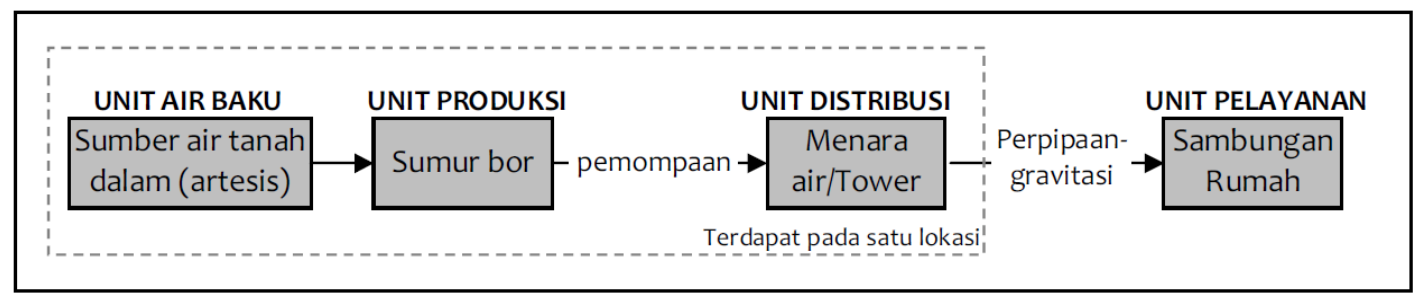

Gambar 2. Sistem Penyedian Air Minum Oleh Pamsimas di Kelurahan Bangetayu Kulon

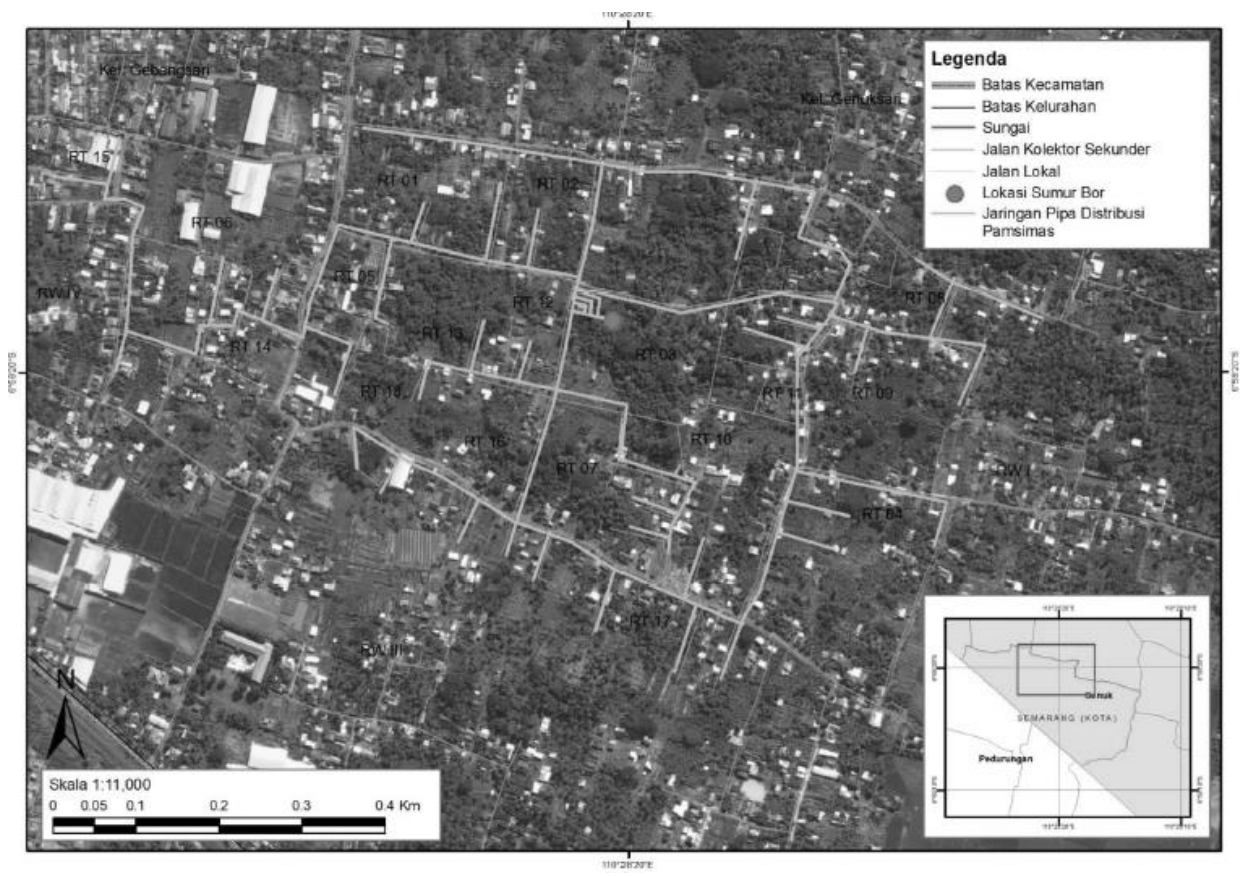

Sumber: RKM Pamsimas Kelurahan Bangetayu Kulon 2009

\section{Gambar 3. Peta Jaringan Air Pamsimas Di RW V Bangetayu Kulon}

\section{Efektivitas Sistem Penyediaan Air Minum oleh Pamsimas}

\section{Pemberdayaan masyarakat}

Secara umum semua tahapan dalam Pamsimas telah dilakukan secara partisipatif melibatkan seluruh komponen masyarakat (miskin-kaya; perempuan-laki-laki). 
Tabel 1. Persentase Keterlibatan Masyarakat

\begin{tabular}{|c|c|c|c|c|c|c|c|c|}
\hline \multirow[b]{2}{*}{ Tahapan } & \multicolumn{2}{|c|}{ Jenis } & \multicolumn{3}{|c|}{ Status sosial } & \multirow{2}{*}{$\begin{array}{l}\text { Jumlah } \\
\text { peserta }\end{array}$} & \multirow{2}{*}{\begin{tabular}{|c|} 
Jumlah \\
penduduk RW \\
V
\end{tabular}} & \multirow{2}{*}{$\begin{array}{l}\text { Persentase } \\
\text { peserta }\end{array}$} \\
\hline & $\mathbf{L}$ & $\mathbf{P}$ & Miskin & Menengah & Kaya & & & \\
\hline $\begin{array}{c}\text { Sosialisasi \& } \\
\text { pelatihan }\end{array}$ & 255 & 158 & 189 & 122 & 102 & 413 & \multirow{8}{*}{2883 jiwa } & $14.33 \%$ \\
\hline IMAS & - & - & 189 & 122 & 102 & 413 & & $14.33 \%$ \\
\hline CLTS & 3 & 14 & - & - & - & 17 & & $0.59 \%$ \\
\hline CTPS & 22 & 8 & - & - & - & 30 & & $1.04 \%$ \\
\hline Pembentukan LKM & 7 & 9 & 4 & 6 & 6 & 16 & & $0.55 \%$ \\
\hline PJM ProAKSi & 16 & 10 & 15 & 5 & 6 & 26 & & $0.90 \%$ \\
\hline Penyusunan RKM & 11 & 17 & 11 & 12 & 5 & 28 & & $0.97 \%$ \\
\hline Pembentukan & 9 & 4 & - & - & - & 13 & & $0.45 \%$ \\
\hline
\end{tabular}

Keterangan: Persentase diperoleh dari perbandingan jumlah peserta ter hadap jumlah penduduk RW V

Namun masih terdapat kekurangan karena pemberdayaan keterlibatan masyarakat dalam kegiatan pembangunan sangat rendah. Dalam kegiatan pelatihan dan pemicuan hanya melibatkan 0,59-14,33\% masyarakat dari total penduduk RW V Kelurahan Bangetayu Kulon.

\section{Peningkatan Perilaku Hidup Bersih dan Sehat}

Berdasarkan indikator ketercapaiannya, Pamsimas di Kelurahan Bangetayu Kulon, terjadi beberapa perubahan perilaku hidup bersih di masyarakat, antara lain:

- Perubahan perilaku BAB di sembarang tempat menjadi BAB dijamban ditandai dengan Tahun 2011, Kelurahan Bangetayu Kulon dinyatakan 100\% STOP BABS.

- Peningkatan perilaku cuci tangan dengan sabun dan air bersih di rumah dan sekolah. Sebelum Pamsimas, 897 KK (33,81\%) sudah menerapkan perilaku CTPS, Setelah ada Pamsimas 1756 KK $(66,19 \%)$.

- Perubahan perilaku siswa dari kebiasaan BAB di sembarang tempat menjadi BAB di jamban karena sarana sanitasi sekolah telah ditingkatkan dan terealisasi $100 \%$.

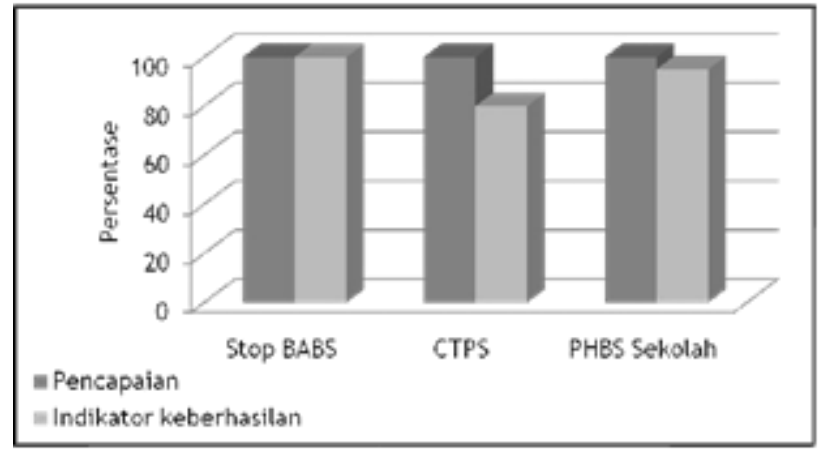

Gambar 4. Diagram Pencapaian Peningkatan PHBS

Dengan demikian derajat kesehatan masyarakat Kelurahan Bangetayu Kulon nantinya akan meningkat. 82,43\% masyarakat pengguna merasakan perubahan kesehatan sejak dilakukannya program Pamsimas. Penyakit diare sudah berkurang dan lingkungan lebih asri karena sudah tidak ada lagi pencemaran. 


\section{Penyediaan Sarana Air Minum dan Sanitasi}

Sarana air minum yang berfungsi di RW V Kelurahan Bangetayu Kulon telah dimanfaatkan serta memenuhi tingkat kepuasan mayoritas masyarakat. Sarana air minum yang dikelola dan dibiayai secara efektif oleh masyarakat melalui kontribusi in- cash dan in-kind. Sarana sanitasi yang berfungsi, dimanfaatkan serta memenuhi tingkat kepuasan mayoritas masyarakat.

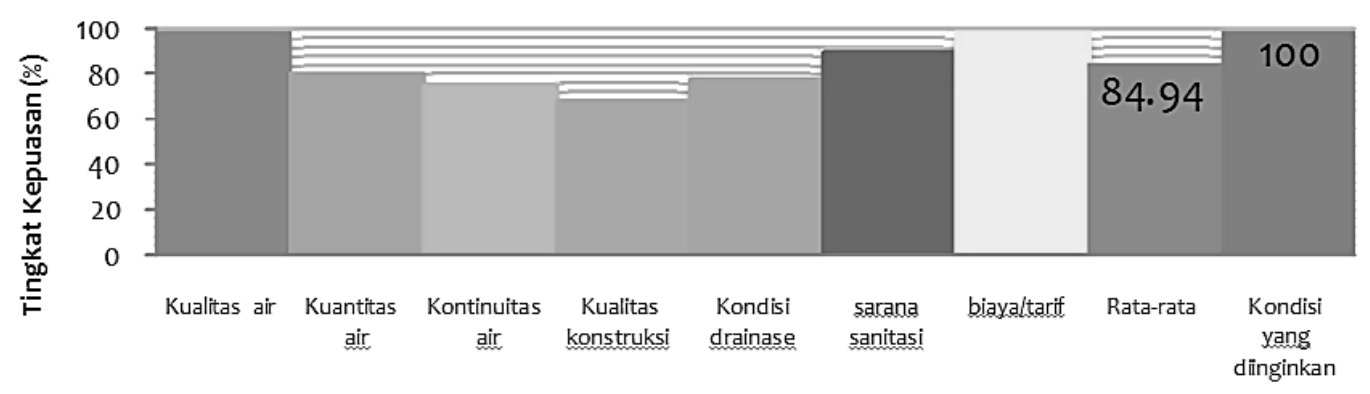

Gambar 5. Grafik Tingkat Kepuasan Masyarakat Terhadap Sarana Air Minum Dan Sanitasi

Secara umum kondisi sarana air minum dari Pamsimas memiliki kualitas yang baik dengan rata-rata 84,94\%, dimana skor kepuasan yang diharapkan adalah $100 \%$. Namun untuk kualitas konstruksi mendapatkan nilai 68,92\%. Jadi masyarakat belum puas sepenuhnya terhadap kondisi sarana air minum yang ada, khususnya untuk kuantitas air, kontinuitas air, kualitas rancangan konstruksi dan kondisi drainase di sekitar sumber air dan jaringan perpipaan.

Berdasarkan ketiga aspek tersebut, sistem penyediaan air minum oleh Pamsimas masih belum efektif, karena keterlibatan masyarakat masih rendah mulai dari tahap awal perencanaan hingga pemeliharaan. Kemudian kurangnya kepuasan masyarakat terhadap kuantitas air, kontinuitas air, kualitas rancangan konstruksi dan kondisi drainase di sekitar sumber air dan jaringan perpipaan.

\section{Analisis Penerapan Konsep WSP-Komunitas dalam Penyediaan Air Minum Berbasis Masyarakat di Kelurahan Bangetayu Kulon}

Analisis ini dilakukan untuk membandingkan antara sistem penyediaan air minum yang dilakukan oleh Pamsimas dan konsep WSP serta mengetahui apakah secara kinerja dan output program Pamsimas sudah sesuai dengan konsep WSP-Komunitas. Komponen WSP yang akan dibandingkan terdiri dari pendekatan pengamanan sistem penyediaan air minum mulai dari sasaran atau target berbasis kesehatan untuk kualitas air, melakukan pendekatan penilaian sistem, melakukan pemantauan operasional tindakan pengendalian, mengembangkan pendokumentasian rencana manajemen dan memberikan pengawasan kesehatan publik dan sistem verifikasi kualitas air.

\section{Identifikasi Resiko pada Titik Kerentanan Bahaya}

1. Resiko pada unit sumber air baku

- Air tanah dalam termasuk dalam zona saturasi dimana pada zona ini air tanah dalam relatif tidak berhubungan/ kontak dengan udara terbuka. 
- Kondisi kualitas air tanah umumnya baik, airnya jernih seperti mata air, tidak berasa dan tidak berbau.

- Tidak terdapat penggunaan lahan yang berpotensi mengancam kualitas sumber air.

2. Resiko pada unit produksi (sumur bor)

- Sumur bor dengan kedalaman 120 meter, telah sampai pada lapisan tanah yang tidak terpengaruh oleh resapan septictank atau intrusi air laut.

- Kuantitas air tanah secara umum memang terbatas dan dipengaruhi oleh musim. Namun air tanah dalam relatif tidak terpengaruh oleh musim.

- Resiko keamanan dari akses orang yang tidak berkepentingan dalam penjagaan sumur bor.

3. Resiko pada unit distribusi

- Kecilnya kemungkinan pengembangan menara air, karena letaknya yang sudah diatas. Sehingga jika akan dilakukan pengembangan dan membutuhkan kapasitas lebih, maka harus membuat menara baru.

- Resiko konstruksi jaringan perpipaan adalah disaat penanaman pipa yang seharusnya ditanam didalam tanah justru banyak yang dipasang di saluran drainase, sehingga banyak terjadi kerusakan.

- Masih banyak saluran air limbah rumah tangga yang belum dibangun dengan baik. Masih berupa tanah saja.

4. Resiko pada unit pelayanan

- Dampak dari resiko pada unit-unit sebelumnya

- Kontinuitas air yang tidak diketahui waktunya

- Jaringan perpipaan sambungan rumah yang melalui drainase

\section{Manajemen Pengamanan Air yang Dilakukan oleh Pamsimas di Kelurahan Bangetayu Kulon}

Penilaian perbandingan antara penerapan konsep WSP dan kinerja penyediaan air minum oleh Pamsimas dianalisis menggunakan analisis skoring.

Tabel 2. Analisis Konsep Penerapan WSP-Komunitas

\begin{tabular}{|c|c|c|c|c|c|c|}
\hline No & $\begin{array}{c}\text { Komponen } \\
\text { Tahapan } \\
\text { WSP } \\
\end{array}$ & WSP-Komunitas & Kinerja Pamsimas & Skor & $\begin{array}{c}\text { Analisis } \\
\text { Perbandingan }\end{array}$ & $\begin{array}{l}\text { Dampak yang } \\
\text { Ditimbulkan }\end{array}$ \\
\hline \multirow[t]{2}{*}{1} & $\begin{array}{l}\text { Pembentukan } \\
\text { tim dan } \\
\text { penentuan } \\
\text { sasaran target } \\
\text { Berbasis } \\
\text { kesehatan }\end{array}$ & $\begin{array}{l}\text { Pembentukan tim } \\
\text { untuk mempersiap- } \\
\text { kan sistem rencana } \\
\text { keamanan air, } \\
\text { dimana tim yang } \\
\text { dibentuk harus } \\
\text { didukung tenaga ahli } \\
\text { sistem penyediaan } \\
\text { air }\end{array}$ & $\begin{array}{l}\text { Tim yang dibentuk } \\
\text { dalam Pamsimas } \\
\text { adalah organisasi } \\
\text { pelaksana, } \\
\text { pengelola dan } \\
\text { pemelihara sistem } \\
\text { penyediaan air. }\end{array}$ & 0 & $\begin{array}{l}\text { Dalam } \\
\text { penyediaan air } \\
\text { oleh Pamsimas } \\
\text { dilakukan oleh } \\
\text { masyarakat yang } \\
\text { dibimbing tim } \\
\text { fasilitator. Tidak } \\
\text { ada tim khusus } \\
\text { pengelola sistem } \\
\text { keamanan air. }\end{array}$ & $\begin{array}{l}\text { Fokus tim } \\
\text { pelaksana dan } \\
\text { pengelola dalam } \\
\text { Pamsimas yang } \\
\text { dilakukan oleh } \\
\text { masyarakat hanya } \\
\text { kepada akses } \\
\text { pelayanan air } \\
\text { minum, tidak } \\
\text { memperhatikan } \\
\text { pengamanan } \\
\text { sistemnya. }\end{array}$ \\
\hline & & $\begin{array}{l}\text { Target untuk } \\
\text { kualitas air } \\
\text { berdasarkan } \\
\text { parameter } \\
\text { mikrobiologi dan } \\
\text { kimia; }\end{array}$ & $\begin{array}{l}\text { Target kesehatan } \\
\text { tidak dijelaskan dari } \\
\text { awal perencanaan. }\end{array}$ & & $\begin{array}{l}\text { Target kesehatan } \\
\text { dalam Pamsimas } \\
\text { lebih kepada } \\
\text { perubahan } \\
\text { perilaku } \\
\text { masyarakat dan }\end{array}$ & $\begin{array}{l}\text { Jika Pamsimas } \\
\text { tidak memiliki } \\
\text { target kesehatan } \\
\text { terkait pencemar an } \\
\text { dan kontaminasi } \\
\text { kualitas air, faktor }\end{array}$ \\
\hline
\end{tabular}


Saura Olivia Effendi 283

\begin{tabular}{|c|c|c|c|c|c|c|}
\hline No & $\begin{array}{c}\text { Komponen } \\
\text { Tahapan } \\
\text { WSP }\end{array}$ & WSP-Komunitas & Kinerja Pamsimas & Skor & $\begin{array}{c}\text { Analisis } \\
\text { Perbandingan }\end{array}$ & $\begin{array}{l}\text { Dampak yang } \\
\text { Ditimbulkan }\end{array}$ \\
\hline & & & & & $\begin{array}{l}\text { perubahan } \\
\text { kesehatan yang } \\
\text { terjadi, diban- } \\
\text { dingkan konsep } \\
\text { WSP yang } \\
\text { mengutamakan } \\
\text { target kesehatan } \\
\text { terkait pencemar } \\
\text { an dan kontami- } \\
\text { nasi air. }\end{array}$ & $\begin{array}{l}\text { ini akan diabaikan } \\
\text { hingga program } \\
\text { selesai dan } \\
\text { mengancam } \\
\text { kesehatan } \\
\text { masyarakat } \\
\text { nantinya. }\end{array}$ \\
\hline \multirow[t]{2}{*}{2.} & $\begin{array}{l}\text { Penilaian } \\
\text { sistem }\end{array}$ & $\begin{array}{l}\text { Tahapan ini } \\
\text { dilakukan untuk } \\
\text { menentukan apakah } \\
\text { rantai penyediaan air } \\
\text { dari sumber air baku } \\
\text { hingga ke konsumen } \\
\text { dapat terlaksana } \\
\text { dengan aman. Pen- } \\
\text { dekatan penilaian } \\
\text { sistem dilakukan } \\
\text { dengan menentukan } \\
\text { apakah siklus penye- } \\
\text { diaan air minum } \\
\text { secara kese-luruhan } \\
\text { mampu memasok air } \\
\text { mencukupi standar } \\
\text { kesehatan yang ada. } \\
\text { Kegiatan ini dapat } \\
\text { dilakukan dengan } \\
\text { cara diskusi kelom- } \\
\text { pok, transek desa, } \\
\text { pemetaan dan } \\
\text { dokumentasi. }\end{array}$ & $\begin{array}{l}\text { Penilaian sistem } \\
\text { dilakukan pada } \\
\text { tahapan identifikasi } \\
\text { masalah dan analisa } \\
\text { situasi (IMAS). } \\
\text { Tahapan ini } \\
\text { dilakukan dengan } \\
\text { meng-identifikasi } \\
\text { kondisi saat ini } \\
\text { terkait akses air } \\
\text { minum, sanitasi, } \\
\text { perilaku kesehatan } \\
\text { dan sanitasi, perma- } \\
\text { salahan dan potensi } \\
\text { sumber daya. }\end{array}$ & 0 & $\begin{array}{l}\text { Penilaian sistem } \\
\text { dalam kegiatan } \\
\text { Pamsimas telah } \\
\text { dilakukan } \\
\text { identifikasi sistem } \\
\text { penyediaan air, } \\
\text { identifikasi } \\
\text { kondisi awal, } \\
\text { identifikasi } \\
\text { masalah dan } \\
\text { situasi melalui } \\
\text { cara diskusi } \\
\text { kelompok, survey } \\
\text { sanitasi, transek } \\
\text { desa, pemetaan } \\
\text { dan dokumentasi } \\
\text { namun tidak } \\
\text { mengidentifikasi } \\
\text { potensi bahaya } \\
\text { yang akan terjadi } \\
\text { dan cara } \\
\text { mencegahnya. } \\
\text { Sehingga program } \\
\text { yang } \\
\text { dilakukan } \\
\text { menyesuaikan } \\
\text { dengan kondisi } \\
\text { yang ada, } \\
\text { menghindari } \\
\text { resiko yang } \\
\text { mungkin muncul } \\
\text { dan menggunakan } \\
\text { sumber yang } \\
\text { potensial untuk } \\
\text { dibangun. }\end{array}$ & $\begin{array}{l}\text { Penilaian sistem } \\
\text { merupakan bagian } \\
\text { terpenting dalam } \\
\text { konsep WSP. Pada } \\
\text { tahapan ini } \\
\text { seharusnya } \\
\text { diidentifikasi } \\
\text { potensi bahaya pada } \\
\text { masing- masing } \\
\text { titik kerentanan } \\
\text { sistem penyediaan } \\
\text { air minum. } \\
\text { Sehingga dengan } \\
\text { adanya penilaian } \\
\text { sistem masyarakat } \\
\text { bersama fasilitator } \\
\text { dapat mencegah dan } \\
\text { meminimalisir } \\
\text { potensi-potensi } \\
\text { bahaya yang } \\
\text { mungkin terjadi } \\
\text { pada sistem. }\end{array}$ \\
\hline & & $\begin{array}{l}\text { Penilaian sistem } \\
\text { dilakukan bersama } \\
\text { tenaga ahli dan } \\
\text { masyarakat yang } \\
\text { lebih paham daerah } \\
\text { mereka, serta } \\
\text { dilakukan sosialisasi } \\
\text { dan pelatihan } \\
\text { terhadap } \\
\text { masyarakat. }\end{array}$ & $\begin{array}{l}\text { Dalam Pamsimas } \\
\text { dilakukan pelatihan } \\
\text { dan pemicuan } \\
\text { perubahan perilaku } \\
\text { hidup bersih dan } \\
\text { sehat, pelatihan } \\
\text { teknis, administras } \\
\text { i, dan sebagainya. }\end{array}$ & 0 & $\begin{array}{l}\text { Setiap kegiat an } \\
\text { pelatihan dan } \\
\text { pemicuan } \\
\text { terhadap } \\
\text { masyarakat telah } \\
\text { dilakukan secara } \\
\text { maksimal } \\
\text { melibatkan } \\
\text { seluruh kelompok } \\
\text { masyarakat (kaya- } \\
\text { miskin, laki- } \\
\text { perempuan) } \\
\text { walaupun dengan } \\
\text { persentase peserta } \\
\text { yang masih } \\
\text { rendah. }\end{array}$ & $\begin{array}{l}\text { Rendahnya } \\
\text { keterlibatan dan } \\
\text { pemahaman } \\
\text { masyarakat akan } \\
\text { berdampak pada } \\
\text { pemeliharaan, } \\
\text { pemantauan dan } \\
\text { pengawasan sistem } \\
\text { pada tahap } \\
\text { selanjutnya. }\end{array}$ \\
\hline
\end{tabular}




\begin{tabular}{|c|c|c|c|c|c|c|}
\hline No & $\begin{array}{c}\text { Komponen } \\
\text { Tahapan } \\
\text { WSP } \\
\end{array}$ & WSP-Komunitas & Kinerja Pamsimas & Skor & $\begin{array}{c}\text { Analisis } \\
\text { Perbandingan }\end{array}$ & $\begin{array}{l}\text { Dampak yang } \\
\text { Ditimbulkan }\end{array}$ \\
\hline 3. & $\begin{array}{l}\text { Pemantauan } \\
\text { operasional } \\
\text { tindakan } \\
\text { pengendalian }\end{array}$ & $\begin{array}{l}\text { Pemantauan } \\
\text { operasional tindakan } \\
\text { pengendalian akan } \\
\text { rantai penyediaan air } \\
\text { minum yang } \\
\text { terjamin kualitasnya } \\
\text { bertujuan untuk } \\
\text { memantau apakah } \\
\text { penyediaan air } \\
\text { sudah sesuai dengn } \\
\text { target dan } \\
\text { mengontrol risiko } \\
\text { yang muncul. }\end{array}$ & $\begin{array}{l}\text { Pemantauan dan } \\
\text { operasional dilaku- } \\
\text { kan oleh } \\
\text { BPSPAMS selaku } \\
\text { pengelola sar ana } \\
\text { air minum dan } \\
\text { sanitasi. } \\
\text { Pemantauan } \\
\text { dilakukan } 3 \text { tahap: } \\
\text { tahap IMAS } \\
\text { (kondisi awal), } \\
\text { tahap setelah } \\
\text { program Pamsimas } \\
\text { selesai dilakukan } \\
\text { dan tahap minimal } \\
\text { satu tahun setelah } \\
\text { program selesai } \\
\text { untuk mengetahui } \\
\text { dampak terhadap } \\
\text { masyarakat. }\end{array}$ & 0 & $\begin{array}{l}\text { Pemant auan } \\
\text { operasional yang } \\
\text { dilakukan pada } \\
\text { program } \\
\text { Pamsimas sebatas } \\
\text { oleh BPSPAMS } \\
\text { saja. Tidak semua } \\
\text { masyarakat } \\
\text { paham cara } \\
\text { memantau kondisi } \\
\text { sarana air dan } \\
\text { sanitasi. Sehingga } \\
\text { banyak kemung- } \\
\text { kinan resiko yang } \\
\text { muncul pada } \\
\text { sistem. Dalam } \\
\text { Rencana Kerja } \\
\text { Masyarakat dalam } \\
\text { Pamsimas tidak } \\
\text { terdapat penjelas- } \\
\text { an resiko dan } \\
\text { penanganan-nya } \\
\text { secara lebih detail } \\
\text { agar lebih } \\
\text { dipahami dan } \\
\text { mudah diterapkan } \\
\text { oleh masyarakat } \\
\text { pengelola dan } \\
\text { pengguna. }\end{array}$ & $\begin{array}{l}\text { Pemantauan yang } \\
\text { dilakukan oleh } \\
\text { Pamsimas belum } \\
\text { sesuai dengan } \\
\text { konsep WSP. } \\
\text { Pemantauan dalam } \\
\text { Pamsimas dinilai } \\
\text { sangat terlambat } \\
\text { karena lebih banyak } \\
\text { dilakukan setelah } \\
\text { program selesai, } \\
\text { disaat masyarakat } \\
\text { sudah merasakan } \\
\text { dampaknya, } \\
\text { kemudian dilakukan } \\
\text { perbaikan dan } \\
\text { penanganan. }\end{array}$ \\
\hline 4. & $\begin{array}{l}\text { Rencana } \\
\text { manajemen } \\
\text { dan } \\
\text { komunikasi }\end{array}$ & $\begin{array}{l}\text { Pendokumentasian } \\
\text { rencana manajemen } \\
\text { terhadap penilaian } \\
\text { sistem dan } \\
\text { pemantauan yang } \\
\text { mendeskrip-ikan } \\
\text { identifikasi penilaian } \\
\text { yang menjelaskan } \\
\text { tindakan yang } \\
\text { diambil selama } \\
\text { kegiatan operasi- } \\
\text { onal, monitoring dan } \\
\text { komunikasi }\end{array}$ & $\begin{array}{l}\text { Penyediaan air oleh } \\
\text { Pamsimas setelah } \\
\text { dilakukan pemba- } \\
\text { ngunan sistem } \\
\text { sarana air, masya- } \\
\text { rakat akan secara } \\
\text { mandiri mengelola } \\
\text { dan memelihara } \\
\text { sarana air minum } \\
\text { dan sanitasi, dan } \\
\text { juga menerapkan } \\
\text { pola perilaku hidup } \\
\text { bersih dan sehat } \\
\text { secara berkelan- } \\
\text { jutan. Tidak ada } \\
\text { pendokumentasian } \\
\text { rencana manajemen } \\
\text { dalam RKM }\end{array}$ & 0 & $\begin{array}{l}\text { Kelemahan } \\
\text { Pamsimas adalah } \\
\text { kurangnya } \\
\text { monitoring dan } \\
\text { pemeliharaan } \\
\text { yang dilakukan, } \\
\text { karena setelah } \\
\text { sistem dibangun, } \\
\text { pemeliharaan } \\
\text { diserahkan } \\
\text { kepada masya- } \\
\text { rakat atau } \\
\text { BPSPAMS } \\
\text { sebagai badan } \\
\text { pengelola. Walau- } \\
\text { pun mereka telah } \\
\text { mendapat-kan } \\
\text { pelatihan, namun } \\
\text { secara teknis } \\
\text { mereka belum } \\
\text { memahami } \\
\text { pentingnya } \\
\text { keamanan dan } \\
\text { potensi resiko } \\
\text { yang akan muncul } \\
\text { serta tindakan } \\
\text { yang harus } \\
\text { dilakukan. Dalam } \\
\text { Rencana Kerja } \\
\text { Masyarakat dalam } \\
\text { Pamsimas tidak } \\
\text { terdapat }\end{array}$ & $\begin{array}{l}\text { Belum adanya } \\
\text { pendokumentasian } \\
\text { rencana manajemen } \\
\text { pengamanan sistem } \\
\text { akan berdampak } \\
\text { pada lemahnya } \\
\text { penga-manan } \\
\text { sistem, lambatnya } \\
\text { penanganan } \\
\text { dampak yang } \\
\text { timbul dan } \\
\text { masyarakat sebagai } \\
\text { pengelola belum } \\
\text { siap untuk } \\
\text { menindaklanjuti } \\
\text { segala bahaya yang } \\
\text { mungkin muncul. } \\
\text { Karena potensi } \\
\text { bahaya, pencegahan } \\
\text { dan penanganannya } \\
\text { tidak diidentifika- } \\
\text { sikan dan ditentu- } \\
\text { kan dari awal } \\
\text { perencanaan }\end{array}$ \\
\hline
\end{tabular}




\begin{tabular}{|c|c|c|c|c|c|c|}
\hline No & $\begin{array}{c}\text { Komponen } \\
\text { Tahapan } \\
\text { WSP } \\
\end{array}$ & WSP-Komunitas & Kinerja Pamsimas & Skor & $\begin{array}{c}\text { Analisis } \\
\text { Perbandingan }\end{array}$ & $\begin{array}{l}\text { Dampak yang } \\
\text { Ditimbulkan }\end{array}$ \\
\hline & & & & & $\begin{array}{l}\text { penjelasan resiko } \\
\text { dan } \\
\text { penanganannya } \\
\text { secara lebih detail } \\
\text { agar lebih } \\
\text { dipahami dan } \\
\text { mudah diterapkan } \\
\text { oleh masyarakat } \\
\text { pengelola dan } \\
\text { pengguna. }\end{array}$ & \\
\hline 5. & $\begin{array}{l}\text { Pengawasan } \\
\text { kesehatan } \\
\text { publik dan } \\
\text { sistem } \\
\text { verifikasi }\end{array}$ & $\begin{array}{l}\text { Manajemen dan } \\
\text { komunikasi terdiri } \\
\text { dari pengadaan } \\
\text { tindakan kolektif, } \\
\text { pengadaan } \\
\text { perekaman data, } \\
\text { validasi pengon- } \\
\text { trolan bahaya dan } \\
\text { verifikasi kualitas } \\
\text { air. }\end{array}$ & $\begin{array}{l}\text { Kegiatan } \\
\text { pengawasan publik } \\
\text { hanya dilakukan } \\
\text { melalui pantauan } \\
\text { badan pengelola } \\
\text { Verifikasi kualitas } \\
\text { air seharusnya } \\
\text { dilakukan } 2 \text { kali } \\
\text { dalam setahun }\end{array}$ & 0 & $\begin{array}{l}\text { Pengawasan } \\
\text { publik dilakukan } \\
\text { oleh badan penge- } \\
\text { lola tidak dilaku- } \\
\text { kan secara sis- } \\
\text { tematis, hanya } \\
\text { menunggu keluh- } \\
\text { an atau laporan } \\
\text { dan masyarakat } \\
\text { Tes kualitas air } \\
\text { tidak dilakukan } \\
\text { rutin sebagaimana } \\
\text { seharusnya. }\end{array}$ & $\begin{array}{l}\text { Lemahnya } \\
\text { pengawasan publik } \\
\text { pada sistem } \\
\text { penyediaan air } \\
\text { minum oleh } \\
\text { Pamsimas } \\
\text { berdampak pada } \\
\text { seluruh kinerja } \\
\text { sistem penyediaan } \\
\text { air minum, mulai } \\
\text { dari identifikasi } \\
\text { pada awal } \\
\text { perencanaan. }\end{array}$ \\
\hline
\end{tabular}

Hal ini berarti pelaksanaan penyediaan air minum Pamsimas masih belum sesuai jika dibandingkan dengan komponen penerapan konsep WSP-Komunitas. Pamsimas belum menerapkan sistem pengamanan yang mencakup semua tahapan seperti konsep WSP, dimana langkah pengamanan baru ditentukan saat program selesai dilaksanakan dan dampak telah dirasakan.

\section{Kesimpulan}

Pelaksanaan penyediaan air minum oleh Pamsimas di Kelurahan Bangetayu Kulon masih belum sesuai dengan penerapan konsep WSP-Komunitas. Dari 5 komponen penerapan WSP, belum satupun kriteria yang dilaksanakan Pamsimas terkait sistem pengamanan air minum. Seperti yang diungkapkan Sam Godfrey and Guy Howard, 2004 dan WHO, 2009, dalam prinsip WSP, pengamanan sistem dilakukan dalam sebuah manajemen risiko yang komprehensif secara keseluruhan yang mencakup semua tahapan mulai dari sumber hingga konsumen sejak awal perencanaan pembentukan tim, target kesehatan, identifikasi penilaian sistem, hingga tahap pengawasan. Pamsimas belum menerapkan sistem pengamanan seperti konsep WSP, dimana langkah pengamanan baru ditentukan saat program selesai dilaksanakan dan dampak telah dirasakan. Dengan penerapan konsep WSP-Komunitas dalam Pamsimas yang mencakup semua tahapan, akan sangat membantu mencegah dan meminimalisir dampak risiko yang akan ditimbulkan serta memantapkan kesiapan masyarakat dalam mengelola dan memelihara keamanan dan keberlanjutan sistem penyediaan air minum yang mereka miliki.

Aspek peran serta masyarakat dalam program Pamsimas yang telah dilakukan masih rendah, karena tidak semua masyarakat berperan aktif dalam kegiatan pelatihan, pemicuan maupun pemeliharaan. Hal ini berdampak pada keefektifan dan keberlanjutan sarana air minum di masa yang akan datang. Sehingga aspek peran serta masyarakat atau kegiatan penyediaan air yang partisipatif menjadi hal penting yang mempengaruhi keandalan suatu sistem penyediaan air minum. Berdasarkan hasil analisa penyediaan air minum oleh 


\section{Penerapan Water Safety Plans (WSP)-Komunitas dalam Penyediaan Air Minum Berbasis Masyarakat}

Pamsimas, bahwa keberhasilan pengamanan sistem air tidak hanya dari kualitas, kuantitas, keberlanjutan dan keterjangkauan sarana air saja, tetapi didukung oleh kondisi sanitasi masyarakat yang berpengaruh pada perubahan kondisi kesehatan masyarakat (Esrey, 1996 dalam Noll, 1999).

Hal ini juga didukung dari hasil temuan studi bahwa aspek finansial, teknis dan kelembagaan dalam sistem penyediaan air minum menjadi penting karena kondisi masyarakat pinggiran kota yang memiliki tingkat ekonomi masyarakat yang rendah dan akses terbatas pada air minum yang aman dan layak. Sehingga penyediaan dan pengamanan air minum komunal berbasis masyarakat sangat sesuai untuk dilakukan sesuai yang dinyatakan oleh Lenton dan Wright, 2004.

\section{Daftar Pustaka}

Amin M. N., C. K. Paul, A. Parvez and M. A. I. Chowdhury. 2011. Context and Prospect of Water Safety Plans in Bangladesh. Journal Environment Science \& Natural Resources, 4(2): 61-71.

Badan Pusat Statistik. Kecamatan Genuk dalam Angka Tahun 2006-2010.

Bappeda Kota Semarang. 2010. Rencana Tata Ruang Wilayah Kota Semarang 2010-2030.

Chusaini, Hajar Ahmad. 2010. The Provision of Clean Water Networks Infrastrukture and Urban Fragmentation Based on Splintering Urbanism Theory in Semarang. Jurnal Pembangunan Wilayah dan Kota, Volume 6, Desember 2010, 55-56.

Godfrey, Sam and Guy Howard. 2004. Water Safety Plans (WSP) for Urban Piped Water

Supplies in Developing Countries. WEDC, Loughborough University, UK.

Godfey, Sam. 2005. Water Quality and Water Safety Plans. WELL Factsheet, May 2005.

Joko, Tri. 2010. Unit Air Baku dalam Sistem Penyediaan Air Minum. Yogyakarta: Graha Ilmu.

Masduqi, A., W. Hadi, N. Endah, dan E.S. Soedjono. 2009. Teknologi Penyediaan Air Bersih Perdesaan: Studi Kasus Di Kabupaten Mojokerto. Seminar Nasional Teknik Sipil V - 2009, ITS Surabaya, 11 Februari 2009.

Mays, L.W. 2004.. Urban Water Supply Management Tools, New York: McGraw Hill Engineering Reference.

Rencana Kerja Masyarakat. 2009. Pamsimas Kelurahan Bangetayu Kulon, Kecamatan Genuk, Semarang.

WASPOLA Facility. 2010. Laporan Bulan September 2010. www.waspola.org. Diakses 5 Desember 2011.

World Health Organization. 2004. Guidelines for Drinking Water Quality. Geneva, Switzerland.

World Health Organization. 2009. Water Safety Plan Manual: Step-by-step risk management for drinking-water suppliers. Geneva. http://www.cdc.gov/nceh/ehs/gwash/wsp.htm. Diakses 5 Desember 2011.

WES UNICEF. 2011. Diskusi Curah Gagasan Konsep Water Safety Plan. 08 September 2011. http://wesriunicef.org/berita.php?id=73. Diakses 5 Desember 2011. 